of contained water the respiration increases regularly up to 25-30 per cent. loss, when it reached two or three times the respiration of similar undried material. Beyond this point drying had no further effect until $50-60$ per cent. of the water had been removed, after which the respiration steadily diminished, not ceasing entirely so long as any water remained in the material.

Prof. W. B. Bottomley gave the results of relative determinations of growth-stimulating "auximones" by means of the bacterial scum formed in their presence on crude nitrifying culture solutions. The relative amounts in fresh and rotted manure and bacterised peat respectively were $I, 5$, and 250 . The formation of auximones during germination was demonstrated; excised embryos were found to flourish in culture solutions only if auximones were added. Culture experiments with Lemna minor showed that the purer fraction precipitated from extracts by silver nitrate stimulates growth more than the cruder phosphotungstic fraction.

\section{Other Papers.}

The only foreign guest of the section, Prof. Julius McLeod, of Ghent, demonstrated the possibility, in the case of certain mosses, of describing and determining species biometrically. Using the genus Mnium, as an example, the maximum, mean, and minimum values for the length, breadth, etc., of the leaves on successive portions of the fertile stem up to the longest leaf were tabulated. The results showed that the correlation between these measurements was characteristic of the species, so that by comparing the length, breadth, etc., of, for instance, the longest leaf of a given specimen with data for the longest leaves of the various species, it could be identified.

Dr. J. C. Willis put forward the view, based on a statistical study of the flora of Ceylon and India, that very local indigenous species are those of recent origin, while species widely distributed on the mainland as well, are those long established. He found no evidence of the elimination of species by "natural selection"; most of the widely distributed species are also common, few rare, while of the endemic species the majority are rare.

Dr. E. J. Salisbury described the influence of coppicing on the ground flora of Oak-Hornbeam woods on clay soils. Before coppicing, it comprises chiefly perennial herbs with storage organs which produce their leaves very early in the spring. After coppicing, species from the edges of the wood and paths invade the opened areas, accompanied by weeds of cultivation with good dispersal mechanisms. Some of the old occupants are enabled by the increased light to flower. The soil becomes more acid and drier. The gradual return of the ground flora to its original condition as the undergrowth thickens was described.

In addition to the contributions already mentioned, Mrs. M. G. Thoday demonstrated the structure of seeds of Gnetum gnemon, Miss E. M. Blackwell dealt with the occurrence of stomata on hypogeal cotyledons, and other smaller demonstrations were given.

\section{Reports.}

Reports on the work of committees of the section were submitted as follows:-By Prof. T. G. B. Osborn, on the cutting of sections of Australian fossil plants; and on Australian Cycadaceæ; by Prof. A. J. Ewart, on investigations of the influence of various atmospheric pressures upon geotropic and heliotropic irritability and curvature; by $\mathrm{Mr}$. R. S. Adamson, on the vegetation of Ditcham Park, Hampshire; by Prof. R. H. Yapp, on the Cinchona Botanic Station in Jamaica; and by Mr. R. P. Gregory, on experimental studies in the physiology of heredity.

NO. 2404, VOL. 96 ]

\section{AGRICULTURE AT THE BRITISH ASSOCIATION.}

A LL interest in agriculture centres at the present time in the economic problems involved in the desired increase of the scope and efficiency of British farming as measured by its output of foodstuffs. It was inevitable, therefore, that the programme of Section M. this year should be largely devoted to the consideration of the existing situation and of the economic factors which govern the introduction of changes in the direction of increased production.

The inaugural address of $\mathrm{Mr}$. Rew, apart from its other merits, served to give the section at the very outset an admirable résumé of the existing situation as regards the share contributed by British agriculture to the national food supplies, and more particularly the extent to which it has assisted during the past year in making good the lack of supplies from sources cut off by the war that under normal conditions would have furnished us with some portion of our food. $\mathrm{He}$ was able to renew the assurance given by him three years ago at Dundee that, even in normal times, the share of British agriculture in the food supply of the nation is more considerable than is commonly realised. Further, he could demonstrate that this share has been substantially increased during the first year of war, whilst, thanks to the Navy, the total supplies which have reached our shores have been actually rather larger in time of war than in time of peace.

After the address, reports upon the present situation and outlook with reference to supplies of manures and feeding-stuffs were presented by Prof. Hendrick and Mr. E. T. Halnan. Prof. Hendrick directed attention to the difficulties that were likely to arise in connection with the supplies of phosphatic manures, especially "dissolved" manures, owing to the increased cost of imported raw materials and the difficulties of distribution. The loss of supplies of potash manures from Germany could be met only to a very slight extent from other sources, but much might be done to reduce existing waste of potasl in the form of loss of liquid manure. The exploitation of seaweed as a source of potash and iodine was also worthy of attention. In a later paper Prof. Hendrick quoted numerous analyses of seaweeds, both Fucus and Laminaria, , which showed that the latter contain appreciable quantities of potash, amounting in some cases to fully 12 per cent. of the dry matter.

Mr. Halnan dealt more particularly with the supply of feeding-stuffs, and summarised the results of tests made at different centres with materials new to the British market, suci? as dried yeast and palm-nut kernel cake.

A further contribution to this day's programme was made by Prof. Somerville, who gave the results of a series of pot-culture experiments which demonstrated clearly the accumulation of fertility in the grass-land of five selected farms as a result of the application of basic slag.

The second day's programme furnished a natural corollary to Mr. Rew's address in the shape of a discussion of various aspects of the present and future agricultural situation as affected by the war. For the purposes of this discussion Mr. T. H. Middleton, Permanent Under-Secretary of the Board of Agriculture and Fisheries, opened the day's programme with an interesting comparison of the efficiency for the production of food of different systems of farming. By ingenious methods of computation he was led to the conclusion that, whereas grazing at its best produces probably not more per acre than sixtyseven days' supply of protein, or I40 days' total supply of energy for a man, and, at its worst, produces no 
more than eleven days' supply of each, dairy farming on grass of good quality might be expected to produce 296 days' supply of protein, or I93 days' total energy supply, whilst arable farming on good land producing food crops and meat would give 207 days' supply of protein, or 296 days' total energy supply. Where grass land is attached to the arable land, and all the feeding materials are converted into milk, the energy value of the arable farm is increased to 367 days' food supply, and the protein yield to 383 days' supply. Viewed from this standpoint, the need for a great extension of arable cropping admits of no argument. "Can the nation any longer afford to neglect the development of the resources now lying latent in its unproductive grass land?"

Mr. J. M. Caie, of the Scottish Board of Agriculture, followed with a paper on "The Probable Effect of the War on the Future of Agriculture in Scotland." After reviewing the salient features of Scottish agriculture and the tendencies of comparatively recent changes prior to the outbreak of war, he outlined the principal economic causes that would tend during and after the war to decrease the demand for and lower the prices of agricultural produce. On the other hand, certain other causes would be operative in diminishing supplies, or otherwise raising prices. Balancing these two sets of factors, he inclined to the opinion that prices, both of bread and of meat, will be relatively high, and that, though costs may also be high, increased production will be economically advantageous to the farmer. He did not think that Scottish agriculture would contribute a materially increased output of wheat, since conditions of soil and climate impose severe limitations, but there is room for expansion in the numbers, and improvement in the quality, of stock. In conclusion, he indicated the factors which would be operative in bringing about this increase of numbers.

Prof. T. B. Wood next spoke on the ways in which the agricultural man of science can assist the stockfeeder in utilising existing conditions to the best advantage. He instanced the introduction of new feeding-stuffs and the prevention of waste in feeding as matters in respect of which the scientific adviser can give immediate and trustworthy guidance to the farmer.

The subject of labour and labour-saving machinery on the farm was dealt with by $\mathrm{Mr}$. W. J. Malden. He emphasised the importance of early-training of the agricultural labourer, and urged the desirability of a reform of educational methods in the rural school with this end in view. The development of the use of machinery on the farm would be more rapid when the implement-maker and the motor-maker joined hands. Confused ideas which the effort to adapt attachments suitable for horse-power, but utterly unsuited for mechanical power, have established must be cleared away.

In the discussion which followed the foregoing papers, Prof. W. H. Thompson gave an account of his own estimates of the food production of Irish agriculture which led to conclusions similar to those arrived at by $\mathrm{Mr}$. Middleton.

A paper on the economics of continuous rropping was subsequently given by $\mathrm{Mr}$. Thomas Wibberley, in which he outlined the results obtained by him on various farms in Ireland and elsewhere by following a course of continuous cropping. He claimed that his system obviated certain practical difficulties of cultivation that beset the ordinary systems, and that it was not only more lucrative and more economical of natural resources, but led to a considerable increase in the output of food. The subiect is one of great interest, and it is to be regretted that limitations of time did not permit of a fuller discussion in the section.

NO. 2404, VOL. 96$]$
The third day's programme was designed to be of special local interest, and was devoted largely to problems of milk-production. One contribution which did not come under this head was the paper by Mr. D. Macpherson and Dr. W. G. Smith on the classification, economic value, and possibilities of improvement of the upland grazings of Scotland. Five types have been recognised, and their distribution and characteristics closely studied. Methods of improvement were indicated and discussed.

Of the milk papers, attention was directed specially to two dealing with the problem of the assessment of the cost of feeding in the production of milk.

Mr. J. Mackintosh gave an account of the methods adopted at University College, Reading, in connection with investigations on farms in the surrounding area.

The outstanding point of difficulty is the assessment of the cost of the home-grown foods consumed by the cows. At Reading these foods are charged at the estimated cost of production, whereas in certain cases elsewhere market or consuming price is charged. The effect of this divergent practice upon the results arrived at was well illustrated in the succeeding paper by Prof. Crowther and Mr. Ruston on the results obtained on three Yorkshire farms. They showed that whereas the estimated cost of food consumed per gallon of milk produced was roughly $3 \frac{1}{2} d$. when homegrown foods were charged at cost of production, the estimate was increased to roughly $5 d$. when an arbitrary scale of "consuming prices" was used for these foods. The subsequent discussion centred mainly round this point, and showed considerable division of opinion. Mr. C. S. Orwin urged strongly the desirability of the universal use of the cost of production of the home-grown foods as the basis of assessment, but practical farmers who took part in the discussion inclined mainly to the opposite view that market prices should be charged.

Subsequently Dr. A. Lauder gave an account of experiments in which the effects upon milk-secretion of an addition of calcium phosphate to the food of cows had been studied. In no case could any measurable effect upon either the yield or the composition of the milk be detected.

Prof. Crowther gave an account of experiments which seemed to indicate that the act of milking may be of considerable significance in determining the yield of milk, and especially of milk-fat obtainable at any particular milking. When the "quarters" were milked separately he found that, whereas in the case of the first quarter the percentage of fat in the secretion rose in the main steadily from beginning to end of the milking. this was not the case with the other "quarters." No matter in what order the "quarters" were milked, the percentage of fat was almost invariably lowest in the milk drawn from the quarter milked last. These observations led to the conclusion that the time-factor in milking must be of considerable importance. This was confirmed by an experimental comparison of quick and slow milking. A further comparison of the ordinary method of milking and simultaneous milking of the four "quarters" showed a difference in favour of the latter, which might in practice be appreciable if certain mechanical difficulties were overcome.

The concluding paper of the programme bv $\mathrm{Mr}$. A. G. Ruston on "The Plant as an Index of Smoke Pollution" introduced another problem of great local interest. Mr. Ruston dealt with the general type of vegetation in smoke-infested areas, the general appearance of individual smoke-damaged plants, and the specific effects of smoke-damage in plants. His remarks were based upon the work on the subject which has been carried out by him and others during the past 
seven years in the agricultural department of the University of Leeds, and were well illustrated by lantern slides. Results were quoted showing a direct correlation between the degree of atmospheric pollution and the activity of plant-growth, the chemical composition of the plant, the activity of the plant enzymes, and the vitality of the seed produced.

The meetings were well attended throughout, and the limited time available for discussion was fully utilised. The proceedings furnished, indeed, abundant evidence that, despite the special circumstances of the year, the steady development of the sertion is being well maintained.

\section{UNIVERSITY AND EDUCATIONAL INTELLIGENCE.}

London.-The Senate of the University passed the following resolution at its meeting on November 17 :"That the Senate desire to express to Lady Rücker and her family their deep sympathy upon the death of Sir Arthur Rücker, who upon the reconstitution of the University in I9O I was appointed its first principal, and to assure them of their profound appreciation of the great services he rendered to the University during his seven years' tenure of that office."

OxFORD.-In the annual report recently issued by the Committee for Geography, after a sympathetic reference to the death of Prof. Herbertson, facts are given showing the steady progress of the school. This is evidenced not only by the increasing number of regular students, but also by the rapid growth of the collections of maps, books, and other apparatus bearing on the subject of geography. The emergency created by the death of the professor has been met for the time by the appointment as acting-directorr of $\mathrm{Mr}$. H. O. Beckit, of Balliol College. Special provision for the wants of different ranks of H.M. Forces training at Oxford has been afforded by lectures and other teaching on the geography of the western war area, the influence of the geography of Greece, and military map-reading. These were given by the professor, Mr. Beckit, Prof. J. L. Myres, and Mr. Kendrew. Mr. A. G. Ogilvie, junior demonstrator, is attached to the staff of the Mediterranean Expeditionary Force in a geographical capacity. The report contains also a grateful acknowledgment of the proposal by the family of Prof. Herbertson to present to the school the considerable number of books lent by him to the library.

IT is announced in the issue of Science for November 5 that $\mathrm{Mr}$. J. J. Hill has presented 25,00ol. to Harvard University to be added to the endowment of the professorship in the Harvard graduate school of business administration which bears his name. The James J. Hill professorship of transportation was founded by a gift of $25,000 l$., announced at the beginning of this session. The General Education Board announces that $20,000 l$. has been given to Carlton College, Northfield, Minn., toward a fund of $80,000 l . ;$ ro,oool. to Hobart College, Geneva, N.Y., toward a fund of $40,000 l$. ; 40,00ol. to Lafayette College, Easton, $\mathrm{Pa}$, , toward a fund of $200,000 l$.; and $5000 l$. to Kalamazoo College, Kalamazoo, Mich., toward a fund of 20,000l.

IN the course of the academic year I9I4-I5 a new department was established on a permanent basis in the Mellon Institute of Industrial Research of the University of Pittsburgh, namely, a Department of Research in Pure Chemistry. The headship of this department is to be known as the Willard Gibbs professorship of research in pure chemistry, "ever to NO. 2404, VOL. 96] proclaim the ideal which the incumbents of the chair and the groups of research workers to be associated with them will be expected to follow." It constitutes a chair in the graduate school of the University of Pittsburgh, as well as in the Mellon Institute. Dr. M. A. Rosanoff, who built up and for years was head of the graduate department of chemistry in Clark University, was formally inaugurated as the first permanent incumbent of this professorship, at a meeting held in the assembly hall of the Mellon Institute on October 26. Addresses were given by Profs. J. McKeen Cattell and M. T. Bogert, both of Columbia University, and by Dr. Rosanoff, followed by a reception and an inspection of the Mellon Institute. Chancellor S. B. McCormick presided at the meeting. He explained the circumstances connected with the establishment of the chair, and thanked the donors whose generosity had made possible the endowment, of which the income, amounting to roool. per annum, is to constitute the salary of the incumbent of the chair.

THE calendar for 1915-16 of King's College, London, contains detailed particulars of the courses of study provided in the various departments of the institution. The work at King's College in connection with the University of London consists of (I) University of London King's College, with faculties of arts, laws, science, and engineering; (2) King's College Theological Department; and (3) University of London King's College for Women. In the case of the College for Women, the arts and science departments were transferred to King's College, Strand, last January, and the Household and Social Science Department is now situated at Campden Hill, London, W. The faculty of engineering provides a systematic course of study of university character for those intending to devote themselves to engineering. It is so arranged as to give preparation for those wishing to take a degree in engineering at the University of London, and the diploma of the college. Owing to the removal of the Strand School, the engineering department has obtained additional accommodation. For electrical engineering a new lecture theatre and rooms for research, including wireless telegraphy, are provided. The new rooms are now ready for use, and the laboratories are well equipped with boilers, steam engines, gas engine, steam turbine, refrigerating and other experimental plant. The scientific principles which underlie all branches of engineering, together with the methods of applying those principles, are taught in carefully arranged and graduated courses. A noteworthy section of the calendar provides a list of original papers and publications issued by the various departments of the college during the year I9I3-r4; it runs to some nine full pages, and is excellent evidence of the facilities for research provided by the authorities.

In March last, Mr. Asquith, in moving the second reading of a Bill to give emergency powers to university authorities, said :- "In no sphere of our national life has the war produced a greater change than in our two ancient Universities." Two recent articles in the Morning Post deal with some of the effects of the war on higher education, and serve excellently to demonstrate that not Oxford and Cambridge alone have responded patriotically and abundantly to the call to arms, but the newer universities have taken up the burden with equal manliness and energy. We have no doubt that when Scottish, Welsh, and Irish universities and those in more distant parts of the Empire are dealt with the author will be able to record an equally glorious response. The most conspicuous result of the war from the point of view of Oxford University has been the immense reduction in the number of undergraduates and of resident fellows of 